\title{
Varicella Zoster Virus Immunization
}

National Cancer Institute

\section{Source}

National Cancer Institute. Varicella Zoster Virus Immunization. NCI Thesaurus. Code C92915.

The administration of a live attenuated viral vaccine to prevent herpes zoster infection. 